\title{
Study on physiological changes of Malvi bullocks during carting bullock drawn sprayer
}

\author{
S.P.S. SOMVANSHI, R. GUPTA, H.P. SINGH AND VENKATA SATISH KUCHI
}

ABSTRACT...... The present study was undertaken to evaluate physiological changes of Malvi bullocks during carting bullock drawn sprayer in soybean. Four healthy Malvi breed bullocks owing 6 to 8 years of age were selected for carting operation research work under Front Line Demonstration (FLD) during 2012-13-2013-14, at village Surkheda of Mandsaur (M.P.) There was a significant $(\mathrm{P}<0.01)$ increase in all the three physiological parameters (respiration rate, pulse rate and body temperature) as compared to their pre-work values.

Author for Corresponding S.P.S. SOMVANSHI

Krishi Vigyan Kendra (RVSKVV), MANDSAUR (M.P.) INDIA

Email : surya.somvanshi@gmail.

com

See end of the article for Coopted authors'
KEY WORDS...... Malvi breed, Physiological response, Bullock drawn sprayer, Physical behavioural

HOW TO CITE THIS ARTICLE - Somvanshi, S.P.S., Gupta, R., Singh, H.P. and Kuchi, Venkata Satish (2017). Study on physiological changes of Malvi bullocks during carting bullock drawn sprayer. Asian J. Animal Sci.,12(2): 117-119. DOI : 10.15740/HAS/TAJAS/12.2/117-119.

ARTICLE CHRONICLE - Received : 30.05.2017; Revised : 05.11.2017; Accepted : 19.11.2017 